accumulation of photosynthetic pigments in them. There were also indicated observable changes in the size of the bark and mechanical tissues of the stem. The effect of the restrictive growth regulators was apparant in the following: the strain of nodule bacteria caused an increase in the linear size of the stem and leaf surface of plants against control. The mutual use of tebuconazole- retardant and strain Bradyrhizobium japonicum led to a decrease in apical dominance of plants, leaf thickness due to increased cell size of wall and spongy parenchymas and intensification of chlorophyll accumulation. Treated plants were characterized by changes in the size of their bark and structural tissues of the stem (collenchyma and sclerenchyma), which is a prerequisite for higher resistance to lodging of plants. The mutual effect of Bradyrhizobium japonicum strain and the triazole preparation proved to be most efficacious among the preparations used. Exogenous application of tebuconazole against the strain of nodule- forming bacteria contributes essentially to the strength of the stem, improves donor functions of Glycine hispida Max, which further secures growth and development of generative organs towards improving yield capasity.

Key words: Cultural soybean, Bradyrhizobium japonicum strain, leaf mesostructure, mechanical tissues, retardant, productivity.

Надійшла 25.11.2020.

УДК 631.582 + 633.14 + 635.652 + 635.655 + 661.163(477.84) doi: 10.25128/2078-2357.20.3-4.14

О. Б. КОНОНЧУК, С. В. ПИДА, А. І. ГЕРЦ, Н. В. ГЕРЦ, О. Б. МАЦЮК, Н. В. МОСКАЛЮК

Тернопільський національний педагогічний університет імені Володимира Гнатюка вул. М. Кривоноса, 2, Тернопіль, 46027

e-mail: kononchuk@chem-bio.com.ua

\title{
ВПЛИВ ПОПЕРЕДНИКІВ І ФУНГІЦИДУ АБАКУС НА ПОШИРЕННЯ ХВОРОБ ТА ПРОДУКТИВНІСТЬ ЖИТА ПОСІВНОГО (SECALE CEREALE L.) В УМОВАХ ТЕРНОПІЛЬСЬКОЇ ОБЛАСТІ
}

Досліджено цінність квасолі звичайної і сої культурної як попередників жита посівного озимого сорту Харківське 98 та дієвість фунгіциду Абакус в умовах Тернопільської області. Виявлено, що пестицид має високу технічну ефективність застосування і зменшує ураження культури фітопатогенами. Поширення хвороб у посіві жита - борошнистої роси, бурої іржі та септоріозу листків не залежало від попередників. Фунгіцид значніше підвищує зернову продуктивність культури, яка висівається після сої, порівняно 3 квасолею, але кращим попередником $є$ квасоля, на що вказує вищий урожай зерна, як під час впливу фунгіциду, так i без його застосування, за рахунок значнішої густоти рослин і стебел, а також збільшення висоти рослин і загального біологічного урожаю. Одержані дані дозволяють рекомендувати розміщувати в сівозмінах жито після квасолі та застосовувати пестицид Абакус як дієві елементи технології вирощування культури в місцевих грунтово-кліматичних умовах.

Ключові слова: жито посівне, сівозміна, попередник, квасоля звичайна, соя культурна, фунгіцид Абакус, хвороба, продуктивність.

Жито посівне (Secale cereale L.) є важливою продовольчою, кормовою і технічною культурою сільського господарства України. Із зерна жита отримують борошно, що містить значну кількість білків - 9-17 \%, легкозасвоюваних вуглеводів - до $80 \%$, ненасичених жирних кислот, 
вітамінів А, $\mathrm{B}_{1} \mathrm{~B}_{2}, \mathrm{~B}_{6}$, Е, РP, С, флавоноїдів, антоціанів, феноламідів, лігнінів тощо, а у складі хліба зумовлює його високу калорійність та особливий присмак і аромат [1].

Жито як кормова культура у тваринництві використовується навесні у вигляді зеленої маси. Зерно жита, як і ячменю, кукурудзи, пшениці, тритикале тощо, входить до складу комбікормів, зокрема для відгодівлі молодняку свиней, але його кількість повинна бути обмежена через гіркі речовини $[7,15]$.

У польових сівозмінах жито відіграє важливе агротехнічне значення як зелене сидеральне добриво та хороший попередник для інших культур. Наприклад, після збирання на зелений корм, воно рано навесні звільняє площі і після нього ще можна успішно вирощувати пізні ярі культури - кукурудзу, просо, гречку та ін. Посіви жита відзначаються швидким ростом, що ефективно пригнічують бур'яни та володіють цінними фітосанітарними властивостями щодо пригнічення розвитку в грунті шкідливих патогенів - нематод і тому $\epsilon$ добрим попередником для картоплі, буряків та інших культур. Для повної реалізації потенційних можливостей самого жита посівного, його необхідно висівати у Лісостепу після кращих попередників - багаторічних трав, озимих та кукурудзи на зелений корм, вико-вівсяних сумішок, гороху, бобів, вики, допускається вирощування після вівса й гречки, а також таких нетрадиційних попередників, як озимий ріпак, ярий ячмінь та соя $[9,15]$. Підбір кращих попередників дозволяє підвищити продуктивність жита на 6-40 \% [16].

Як технічну культуру житнє зерно використовують для виробництва високоякісного спирту, солому - для виготовлення паперу, матів, кошиків, целюлози, оцту та інших продуктів $[15,16]$.

На території України вирощують переважно озиму форму жита посівного, якій притаманні висока продуктивність та специфічні біологічні особливості, такі як висока морозостійкість, пристосованість до кислої реакції грунтів, значна засвоювальна здатність мінеральних елементів живлення, високий потенціал кущення, стійкість до весняної посухи тощо $[12,15]$.

Однак, не зважаючи на цінність і затребуваність, посівні площі жита в Україні скорочуються, а його врожайність не відповідає біологічним можливостям культури. Зокрема, у 2007 р. площа вирощування жита становила 337,4 тис. га із урожайністю зерна 16,7 ц/га, у 2017 p. - 171,0 і 29,7, у 2018 р. - 148,4 і 26,5, відповідно [19].

Збільшення виробництва жита в сучасних умовах за рахунок розширення посівних площ залишається проблемним завданням через домінування i високу затребуваність на внутрішньому і зовнішніх ринках, у першу чергу, зерна пшениці й кукурудзи. Отож, зростання валового збору зерна жита в Україні доцільно пов' язувати із підвищенням його продуктивності через підбір високоурожайних сортів і гібридів, кращих попередників у сівозмінах, із дотриманням оптимальних строків і способів сівби, із внесенням мінеральних добрив, 3 ефективною системою догляду, яка б зменшувала пошкодження культури шкідниками i хворобами тощо $[5,10,12,15,22]$.

Наприклад, на території України в посівах жита виявлені сажкові й іржасті хвороби, кореневі гнилі, ріжки, плямистості, бактеріальні та вірусні захворювання, які можуть бути причиною недобору урожаю культури у 10-20\%. За умов інтенсифікації вирощування жита, як і інших зернових культур, втрати від хвороб можуть сягати більше 50 \% [10,18].

У зв'язку з цим, одним із важливих напрямків досліджень для зменшення втрат від хвороб і підвищення продуктивності жита посівного озимого є вивчення впливу на культуру різних попередників та ефективності застосування фунгіцидів у конкретних грунтовокліматичних умовах $[9,10,12]$.

Відповідно зазначеного вище, метою роботи було дослідити цінність квасолі звичайної і сої культурної як попередників та ефективність захисту фунгіцидом Абакус жита посівного озимого за показниками поширення хвороб і продуктивністю в грунтово-кліматичних умовах Тернопільської області. 


\section{Матеріал і методи досліджень}

Матеріалом дослідження було жито посівне озиме вітчизняного сорту Харківське 98, яке визнане придатним для поширення у всіх грунтово-кліматичних зонах України [3].

Сорт характеризується підвищеною зимостійкістю, високою посухостійкістю, нижчою, порівняно із стандартом й іншими сортами, ураженістю борошнистою росою, бурою іржею $\mathrm{i}$ сніговою пліснявою, стійкістю до вилягання і осипання, крупним зерном (маса 1000 зерен досягає 50-55 г), добре розвиненою кореневою системою тощо. Сорт має високу й стабільну урожайність - до 93,3 ц/га [4].

Для захисту жита від хвороб використовували фунгіцид Абакус (Abacus ${ }^{\circledR}$ ), який $€$ двокомпонентним пестицидом 3 двома механізмами дії від німецької фірми BASF, що рекомендований до застосування на зернових колосових культурах, кукурудзі, сої і цукрових буряках [2].

Абакус включає два інгредієнти контактної і системної дії для боротьби із хворобами піраклостробін і епоксиконазол концентрацією 62,5 г/л кожен, які захищають всі органи рослини за рахунок профілактики проростання спор, інфекцій та росту міцелію гриба, обмеження вторинного зараження на пізніх стадіях росту рослин $[1,2]$.

Крім фунгіцидної активності, піраклостробін, один із активних інгредієнтів Abacus ${ }^{\circledR}$, виявляє властивості стимулятора фізіологічних процесів у рослинах (AgCelence ${ }^{\circledR}$-ефект) підвищує ефективність використання води, інтенсифікує засвоєння азоту, збільшує поглинання $\mathrm{CO}_{2}$ i накопичення крохмалю, пригнічує утворення в рослинах етилену за стресових умов тощо, що в цілому сприяє зростанню врожаю навіть за слабкого захворювання культури [1].

Польові досліди проводили на території агробіолабораторії Тернопільського національного педагогічного університету імені Володимира Гнатюка на важкосуглинистому чорноземі типовому із дуже високим вмістом обмінного калію (189 мг/кг), низьким вмістом легкогідролізованого азоту (102 мг/кг), сірки (2,6 мг/кг), кобальту $(0,09$ мг/кг) і цинку $(1,05$ мг/кг), середньою забезпеченістю гумусом в орному шарі (2,63\%), рухомим фосфором (71 мг/кг), марганцем $(9,34$ мг/кг), близькою до нейтральної обмінною $(p H 5,6)$ i гідролітичною (2,16 мг-екв./100 г) кислотністю грунтового розчину тощо.

Жито посівне вирощували за загальноприйнятою для Лісостепу України технологією [12, 15], але без застосування мінеральних добрив, гербіцидів та інсектицидів. Сівбу здійснювали розкидним способом сівалкою-розкидувачем Gardena XL.

Під час вегетації жито двічі у фенологічну стадію подовження стебла (ВВСН 32 і 39) [20] обробляли фунгіцидом Абакус 3 нормою витрати 1,5 л/га та 300 л/га розчину ранцевим оприскувачем. Рослини контрольного варіанту зволожували водою.

Розміщення варіантів досліду послідовне із 4-разовим повторенням, відповідно рекомендованої для випробовування фунгіцидів методикою [14].

Через 10 діб після останнього обприскування жита фунгіцидом Абакус у стадію вихід у трубку проводили обстеження контрольних $\mathrm{i}$ дослідних рослин на розповсюдження (поширеність) хвороб, на основі яких розраховували технічну ефективність дії пестициду [14].

Визначення величини й елементів структури урожаю жита здійснювали після повного достигання зерна методом пробних майданчиків [6].

Повторення досліджень від 4 до 30 і більше разів. Статистичне опрацювання даних проводили за допомогою програми Microsoft Excel $^{\circledR}$.

\section{Результати досліджень та їх обговорення}

Обстеження посівів жита сорту Харківське 98 показало, що в умовах вегетаційного сезону 2018-2019 рр. надземні органи культури вражалась борошнистою росою, бурою іржею та септоріозом листків.

Поширення борошнистої роси на житі посівному, яке висівалось після квасолі, становило $5,3 \%$, а після сої - 5,0 \% (контрольні варіанти). Застосування фунгіциду Абакус статистично вірогідно знижувало розповсюдження хвороби на 2,7 \% і 3,0 \% (дослідні варіанти) відповідно (табл. 1). 
Незначне поширення борошнистої роси в досліджуваний період (стадія вихід у трубку) можна пояснити жаркими погодними умовами і дещо зрідженим станом стеблостою, адже активний розвиток патогена спостерігається на затінених рослинах. Затримує розвиток хвороби висока температура повітря (понад $\left.30^{\circ} \mathrm{C}\right)[13,17]$.

Бура іржа вражала 5,9 \% рослин жита, яке було висіяно після квасолі, та 6,9 \% після попередника - сої. Дворазове обприскування фунгіцидом зменшило поширення хвороби до рівня 3,0\% і 3,7 \% уражених рослин відповідно (табл. 1 ).

Інфекція бурої іржі на житі, як і пшениці, поширюється із решток стерні чи падалиці урединіоспорами за допомогою вітру, дощу, але влітку, за умов підвищеної вологості й тепла, спори зберігають свою життєздатність недовго [17], що, на нашу думку, і пояснює незначне поширення хвороби. Крім того, відносно стійкими до бурої іржі є сорти жита селекції Інституту рослинництва ім. В.Я. Юр'єва НААНУ (м. Харків) [4], до яких і належить досліджуваний сорт Харківське 98.

Дещо вищу шкодочинність для жита виявляв септоріоз листя. Розповсюдження хвороби у культурі, яка була висіяна після квасолі, становило $8,7 \%$, після сої - 10,1 \% (табл. 1). Таке незначне поширення хвороби можна пояснити сухою і жаркою погодою 2019 р., коли були проведені дослідження, адже септоріоз особливо сильно розвивається в періоди 3 підвищеною кількістю опадів і температурою $20-20^{\circ} \mathrm{C}$ [13]. За підвищеної температури і сухості повітря життєздатність пікноспор зберігається лише біля трьох місяців [18].

Застосування фунгіциду Абакус знизило поширення септоріозу листя жита сорту Харківське 98 на 6,0 \% після розміщення за квасолею і 7,1 \% - за соєю (табл. 1).

Розрахунок технічної ефективності дії фунгіциду Абакус показав його високу дієвість, щодо борошнистої роси, бурої іржі і септоріозу листя жита посівного незалежно від попередників культури.

Так, технічна ефективність пестициду проти борошнистої роси на житі, що було висіяно після квасолі, становила 50,2 \% та після сої - 58,7 \%, проти бурої іржі - 49,2 \% і 46,9 \% відповідно. Вищу дієвість фунгіцид Абакус виявляв у боротьбі із септоріозом листків (технічна ефективність $69,5 \%$ і 70,5 \%) після розміщення жита за попередниками - квасолею і соєю відповідно (табл. 1).

Отже, поширення хвороб у посіві жита посівного сорту Харківське 98 - борошнистої роси, бурої іржі та септоріозу листків у досліджуваний вегетаційний сезон не залежало від попередників - квасолі чи сої, як і висока технічна ефективність застосування фунгіциду Абакус у боротьбі з ними.

Таблиия 1

Розповсюдження хвороб і технічна ефективність фунгіциду Абакус залежно від попередника у посіві жита посівного озимого сорту Харківське 98, \%

\begin{tabular}{|c|c|c|c|c|}
\hline \multirow{2}{*}{ Хвороба } & \multicolumn{2}{|c|}{ Попередник квасоля } & \multicolumn{2}{|c|}{ Попередник соя } \\
\hline & контроль & дослід & контроль & дослід \\
\hline борошниста роса & $5,3 \pm 0,5$ & $2,6 \pm 0,3^{*}$ & $5,0 \pm 0,3$ & $2,0 \pm 0,2 *$ \\
\hline технічна ефективність & - & 50,2 & - & 58,7 \\
\hline бура іржа & $5,9 \pm 0,2$ & $3,0 \pm 0,4^{*}$ & $6,9 \pm 0,5$ & $3,7 \pm 0,3 *$ \\
\hline технічна ефективність & - & 49,2 & - & 46,9 \\
\hline септоріоз листя & $8,7 \pm 0,8$ & $2,7 \pm 0,3^{*}$ & $10,1 \pm 0,8$ & $3,0 \pm 0,2 *$ \\
\hline технічна ефективність & - & 69,5 & - & 70,5 \\
\hline
\end{tabular}

Примітка: * - p<0,05 різниця вірогідна порівняно з контролем

Визначення величини та елементів структури урожаю жита посівного сорту Харківське 98 виявило високий вплив попередника та значну дієвість фунгіциду Абакус за більшістю із досліджуваних показників (табл. 2).

Так, густота рослин жита, яке було висіяно після попередника квасоля, була вищою на 101,0 рослину/м² у контрольних варіантах і на 71,3 - за обробки пестицидом. Аналогічно

ISSN 2078-2357. Наук. зап. Терноп. нац. пед. ун-ту. Сер. Біол., 2020, № 3-4 (80) 
зростала загальна густота стебел - на 32,2 \%, порівняно із попередником - соя, за відсутності обробки, та на $21,7 \%$ - за обприскування фунгіцидом, а також їхня продуктивна кількість - на $20,0 \%$ і 17,6 \% відповідно (табл. 2).

Зазначені зміни у кількості рослин і їх стебел на одиницю площі поля, залежно від попередника, вплинули на здатність рослин кущитись. За середньої загальної кущистості в контрольному і дослідному варіантах культури, яка висівалась після квасолі - 1,5 шт., рослини за висіву після сої кущились інтенсивніше - 2,0 шт. Аналогічні зміни відбувались і 3 продуктивною кущистістю - 1,3 шт. після розміщення за квасолею і 1,75 шт. - за соєю. Зазначені зміни значнішої інтенсивності кущення рослин жита за висіву після сої необхідно пов' язувати із їх нижчою густотою, яка стимулює цей процес [12].

Обприскування пестицидом культури, яка висівалась після квасолі, незначно вплинуло на зміну густоти рослин (підвищення 2,8 \% до контролю), та істотно зросло (на 26,9 \%) після сої. Фунгіцид Абакус статистично вірогідно підвищував загальну й продуктивну густоту стеблостою та загальну кущистість культури, як за вирощування після квасолі - на 25,3, 18,6 і $14,3 \%$, так і після сої - на 36,1, 21,1 і 22,2 \% відповідно. Виявлена тенденція до зростання на 5,9 \% до контролю продуктивної кущистості жита після сої та відсутність змін після квасолі (табл. 2).

Вищі показники зростання за дії фунгіциду Абакус кількості рослин і стебел жита, яке було висіяно після сої, на нашу думку, пов'язані із його меншою густотою [12], що дозволяло рослинам значніше реагувати на дію препарату, адже оптимальна густота продуктивного стеблостою для озимого жита становить 450-500 шт./м² [15].

На вищу цінність квасолі як попередника для жита вказує більша середня висота рослин як за обробки фунгіцидом, так і без неї - на 6,0 \% порівняно із рослинами, що росли після сої, $169,3 \pm 0,9$ см (табл. 2).

За дії фунгіциду Абакус рослини жита були вищими на 8,1 \% до контролю за вирощування після квасолі і на $2,4 \%$ - сої (табл. 2), що можна пов'язувати із відомим AgCelence ${ }^{\circledR}$-ефектом препарату, який активує в рослинах фізіологічні процеси [1].

Визначення довжини колоса, кількості колосків у суцвітті, кількості і маси зерен у колосі показало, що зазначені елементи продуктивності мало залежали від розміщення жита у сівозміні після квасолі чи сої. Маса 1000 насінини культури в контрольному варіанті після розміщення за соєю була статистично вищою на $3,7 \%$, порівняно із вагомістю насіння аналогічного варіанту, який висівали після квасолі, що пов'язано із меншою густотою рослин [12]. Застосування фунгіциду Абакус у дослідних варіантах нівелювало вплив попередника на зазначений показник - тенденція вищої вагомості насіння після сої збереглася, але вона вже не була статистично вірогідною порівняно із величиною насіння жита, що висівалось за квасолею (табл. 2).

Фунгіцид Абакус більшою мірою впливав на формування колосся жита, яке мало на 4,6\% більшу кількість зерен за вирощування після квасолі і на 13,2 \% - після сої, маса 1000 зерен зростала на 4,7 \% і 4,6 \% відповідно, що сприяло підвищенню маси зерна у колосі на $9,5 \%$ і $19,1 \%$ у зазначених варіантах. Суттєвих змін у довжині колоса і кількості в ньому колосків за дії препарату, як і попередника, не було встановлено (табл. 2).

Зазначене зростання кількості і маси зернівок у колосі жита та його величини (маси 1000 насінин) під впливом фунгіциду Абакус можна пояснити відомим стимулювальним впливом препарату на вуглецевий цикл, засвоєння і використання азоту тощо за рахунок вищої здатності рослин накопичувати в листках більше азотистих сполук і вуглеводів та транспортувати їх у зернівки [1], а також, очевидно, із зростанням фертильності пилку і зменшенням абортивності квіток колоса [12].

Відомо, що на формування маси зернівки хлібних злаків впливає чимало факторів, зокрема, розмір і тривалість активної роботи асиміляційного апарату верхньої частини рослин, тривалість формування зернівки, умови живлення рослин під час дозрівання врожаю, ураження рослин хворобами тощо [12], на які також активно впливав досліджуваний фунгіцид Абакус. 
У результаті збирання урожаю жита посівного сорту Харківське 98 виявлено, що продуктивність культури залежала від попередника. Так, середній біологічний урожай надземної маси рослин жита у контрольному і дослідному варіантах після висіву за квасолею $(283,6$ ц/га) був на 83,5 ц/га більшим, порівняно із попередником - соя. Аналогічно зростав на 6,6 ц/га середній біологічний урожай зерна і на 77,8 ц/га - соломи (табл. 2), що вказує на вищу цінність квасолі як попередника для жита посівного озимого, порівняно із соєю.

Квасоля більшою мірою, порівняно із соєю, стимулювала наростання вегетативної маси рослин жита, ніж урожаю зерна, адже середній вихід зерна в рослин контрольного і дослідного варіантів, які були вісіяні після неї, становив 22,9\%, а після сої - 29,7 \%.

Визначення продуктивності жита, яке вирощували після квасолі, виявило, що дворазове обприскування культури пестицидом статистично вірогідно підвищувало на 30,4 \% до контролю біологічний урожай надземної маси рослин та його складових частини - на 30,6 \% соломи і на $29,4 \%$ або 16,6 ц/га зерна (табл. 2).

Значнішим був стимулюючий вплив фунгіциду на жито після попередника - соя, адже зростання біологічного урожаю надземної маси рослин становило 38,4 \%, урожаю соломи $36,8 \%$ і зерна $-43,1 \%$ до контролю.

Одночасна активізація фунгіцидом формування урожаю зерна і ростових процесів у вегетативних органах рослин, що проявлялась у зростанні біологічного урожаю соломи, стала причиною незначних змін у виході зерна дослідних варіантів: після вирощування культури за квасолею - тенденція до зниження на $1,3 \%$, після сої - неістотне зростання на 3,8 \% (табл. 2).

Таблиия 2

Вплив попередника і фунгіциду Абакус на продуктивність жита посівного сорту Харківське 98

\begin{tabular}{|c|c|c|c|c|}
\hline \multirow{2}{*}{ Показник } & \multicolumn{2}{|c|}{ Попередник квасоля } & \multicolumn{2}{|c|}{ Попередник соя } \\
\hline & контроль & дослід & контроль & дослід \\
\hline густота рослин, шт./M² & $236,0 \pm 10,8$ & $242,6 \pm 12,8$ & $135,0 \pm 5,0$ & $171,3 \pm 2,1^{*}$ \\
\hline густота стебел загальна, шт./м² & $316,2 \pm 4,6$ & $396,1 \pm 4,9^{*}$ & $239,2 \pm 16,1$ & $325,5 \pm 2,5^{*}$ \\
\hline густота стебел продуктивних, шт./м² & $270,0 \pm 3,5$ & $320,2 \pm 1,6^{*}$ & $225,0 \pm 6,9$ & $272,4 \pm 4,9^{*}$ \\
\hline кущистість загальна, шт. & $1,4 \pm 0,20$ & $1,6 \pm 0,10^{*}$ & $1,8 \pm 0,17$ & $2,2 \pm 0,04 *$ \\
\hline кущистість продуктивна, шт. & $1,3 \pm 0,11$ & $1,3 \pm 0,01$ & $1,7 \pm 0,15$ & $1,8 \pm 0,05$ \\
\hline висота рослин, см & $172,5 \pm 1,5$ & $186,4 \pm 1,9^{*}$ & $167,3 \pm 1,1$ & $171,3 \pm 0,7 *$ \\
\hline довжина колоса, см & $10,9 \pm 0,32$ & $11,0 \pm 0,17$ & $11,7 \pm 0,16$ & $11,6 \pm 0,22$ \\
\hline кількість колосків у колосі, шт. & $34,4 \pm 0,7$ & $33,8 \pm 0,3$ & $33,1 \pm 0,8$ & $33,1 \pm 0,8$ \\
\hline кількість зерен у колосі, шт. & $54,6 \pm 0,9$ & $57,1 \pm 0,5^{*}$ & $53,6 \pm 0,8$ & $60,8 \pm 1,0 *$ \\
\hline маса зерна у колосі, г & $2,1 \pm 0,05$ & $2,3 \pm 0,03 *$ & $2,1 \pm 0,03$ & $2,5 \pm 0,03 *$ \\
\hline маса 1000 зерен, Г & $38,2 \pm 0,3$ & $40,0 \pm 0,3^{*}$ & $39,6 \pm 0,2$ & $41,4 \pm 0,5^{*}$ \\
\hline біологічний урожай надзем. маси, ц/га & $246,2 \pm 13,6$ & $321,0 \pm 4,5^{*}$ & $167,9 \pm 12,6$ & $232,3 \pm 14,6^{*}$ \\
\hline біологічний урожай зерна, ц/га & $56,4 \pm 2,0$ & $73,0 \pm 0,5^{*}$ & $47,8 \pm 2,2$ & $68,4 \pm 1,4 *$ \\
\hline біологічний урожай соломи, ц/га & $197,2 \pm 11,9$ & $257,5 \pm 4,2^{*}$ & $126,3 \pm 9,2$ & $172,8 \pm 8,7 *$ \\
\hline вихід зерна, \% & $23,0 \pm 0,5$ & $22,7 \pm 0,2$ & $29,1 \pm 1,6$ & $30,2 \pm 3,9$ \\
\hline
\end{tabular}

Примітка: * - p<0,05 різниця вірогідна порівняно з контролем

Незважаючи на те, що реакція рослин жита на застосування фунгіциду Абакус була значнішою після попередника соя культурна за багатьма досліджуваними елементами продуктивності, урожай, зокрема зерна, був на 8,6 ц/га у контрольному і на 4,6 ц/га у дослідному варіантах нижчим, ніж після висіву культури за квасолею звичайною. Це вказує на вищу цінність квасолі як попередника для жита в місцевих грунтово-кліматичних умовах.

Так, за відсутності обробки фунгіцидом у контролі, жито, яке було висіяне після квасолі, відзначалось статистично вірогідним зростанням на 75,8 \% густоти рослин, 32,2 \% загальної густоти стебел, 20,0 \% густоти продуктивних стебел, порівняно з аналогічними показниками за попередника соя. Зазначене збільшення показників густоти рослин та дещо менше зростання густоти загального й продуктивного стеблостою зумовили тенденцію до зниження інтенсивності кущення. Вимірювання довжини колоса, підрахунок кількості колосків і зерен у

ISSN 2078-2357. Наук. зап. Терноп. нац. пед. ун-ту. Сер. Біол., 2020, № 3-4 (80) 
суцвіттях та зважування маси зерна у колосах показали незначний вплив попередників на ці показники. Величина ж насіння була статистично вищою на $3,5 \%$ у рослин, які висівали після сої культурної, що в цілому не вплинуло на переважання квасолі як попередника, адже біологічний урожай надземної маси жита, що було висіяно після неї, був на 46,6 \% вищим, порівняно із попередником соя, біологічний урожай зерна - на $18,0 \%$ і біологічний урожай соломи - на $56,1 \%$ (рис. $a$ ).

Значніше зростання показників маси соломи (56,1 \%), порівняно із 18,0 \% збільшенням урожаю зерна у жита, що було висіяно після квасолі, порівняно з попередником соя, а також зменшення на 6,1 \% виходу зерна, вказує на значніший стимулюючий вплив попередника квасоля саме на ріст вегетативних органів рослин та менш виражену дію на формування генеративних органів. Зазначені зміни, очевидно, пояснюються нижчим вмістом у грунті доступних форм азоту після сої та вищим - після квасолі.

Обприскування посівів жита фунгіцидом Абакус дещо зменшило переважання попередника квасоля, порівняно із соєю, на формування продуктивності жита та їі елементів (рис. б).

Так, за обробки фунгіцидом, жито, що було висіяно після попередника квасоля, характеризувалося зростанням густоти рослин на $41,6 \%$, загальної густоти стебел $-21,7 \%$, густоти продуктивних стебел - 17,5 \% та показника висоти стебла - 8,8 \% порівняно із рослинами, що розміщувалися за соєю. Зазначене збільшення густоти рослин та менше зростання густоти загального й продуктивного стеблостою зумовило зниження показників загального й продуктивного кущення рослин на 27,3 \% і 27,8 \% відповідно. Вимірювання довжини колоса, підрахунок кількості колосків у суцвіттях та визначення маси 1000 насінин виявили незначний вплив попередників на ці показники. Кількість і маса зерен у колосі рослин, які висівали після сої, були вищими на 6,1 \% і 8,0 \% відповідно, що в цілому підтвердило попередні результати стосовно квасолі як попередника, адже біологічний урожай надземної маси рослин жита після квасолі зростав на $38,2 \%$, зерна - на 6,7 \% і соломи - на 49,0 \% порівняно із попередником соя, зберігаючи аналогічну тенденцію до зниження виходу зерна у культури на 7,5\% через значніше наростання вегетативної маси та обмежений вплив попередників на генеративну сферу рослин (рис. б).

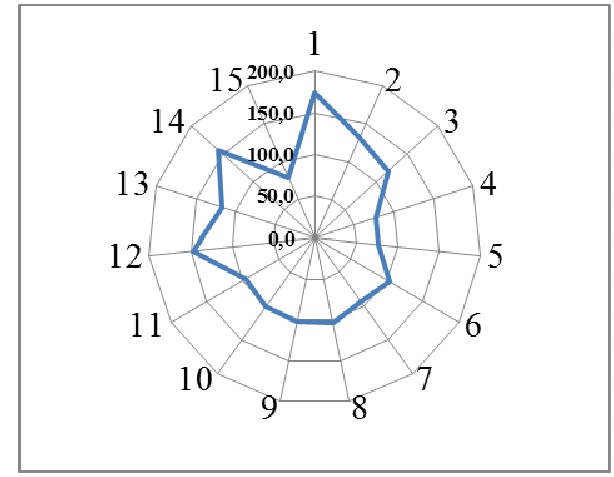

$a$

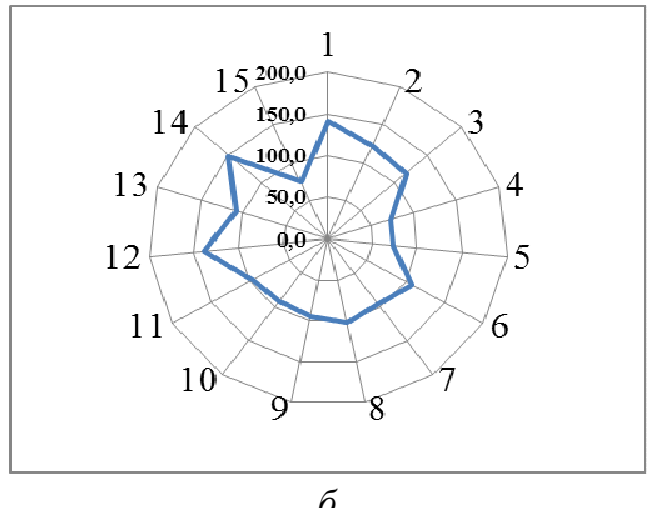

$\sigma$

Рис. Вплив попередника квасоля на продуктивність жита посівного сорту

Харківське 98 за відсутності (a) та після обприскування фунгіцидом Абакус (б), \% до попередника соя.

Умовні позначення: 1 - густота рослин, 2 - густота стебел загальна, 3 - густота стебел продуктивних, 4 - кущиистість загальна, 5 - кущчистість продуктивна, 6 висота рослин, 7 - довжина колоса, 8 - кількість колосків у колосі, 9 - кількість зерен у колосі, 10 -маса зерна у колосі, 11 -маса 1000 зерен, 12 - біологічний урожай надземної маси, 13 - біологічний урожай зерна, 14 - біологічний урожай соломи, 15 - вихід зерна.

Таким чином, зростання густоти й висоти рослин та кількості стебел на одиниці площі були визначальними у формуванні вищого біологічного урожаю зерна й соломи жита посівного 110 ISSN 2078-2357. Наук. зап. Терноп. нац. пед. ун-ту. Сер. Біол., 2020, № 3-4 (80) 
сорту Харківське 98 після його розміщення в сівозміні за квасолею, порівняно із попередником соя, хоч і застосування гербіциду Абакус зменшувало цю різницю.

\section{Висновки}

Абакус у грунтово-кліматичних умовах Тернопільської області зменшує поширення борошнистої роси у посіві жита сорту Харківське 98 після попередників квасоля і соя на 2,7 i $3,0 \%$, бурої іржі - 2,9 і 3,2 \%, септоріозу листків - 6,0 і 7,1 \%. Він проявляє високу технічну ефективність застосування проти зазначених вище хвороб, зокрема 50,2 і 58,7 \%, 49,2 і 46,9 \%, 69,5 і 70,5 \% відповідно. На ступінь ураження рослин жита зернобобові попередники не впливали.

Пестицид значніше (на 20,6 ц/га) підвищує зернову продуктивність жита, яке висівали після сої, і на 16,6 ц/га - після квасолі. Такі результати зростання урожаю зерна жита після попередника соя за дії фунгіциду пов'язані, перш за все, із значнішим формуванням густоти рослин і стеблостою, збільшенням кількості і маси зернівок у колосі та значнішого приросту біологічного врожаю надземної маси.

Незважаючи на вищу ефективність фунгіциду Абакус у посіві жита після сої, доцільнішим попередником для культури в місцевих грунтово-кліматичних умовах $€$ квасоля, на що вказує вищий урожай зерна як під час застосування фунгіциду Абакус - на 4,6 ц/га, так i за його відсутності - на 8,6 ц/га.

Аналіз елементів продуктивності виявив, що вища цінність квасолі як попередника жита, порівняно із соєю, реалізується незалежно від застосування пестициду за рахунок вищої на 41,6-74,8 \% густоти рослин, 21,7-32,2 \% загальної густоти стебел і 17,5-20,0 \% густоти продуктивних стебел, а також збільшення на $3,1-8,8$ \% висоти стебла, що зумовлює зростання загального біологічного урожаю рослин на $38,2-46,6$ \% та його складової - маси соломи на $49,0-56,1 \%$.

Зважаючи на вищу цінність квасолі, порівняно із соєю як попередника жита, за його продуктивністю та відсутністю значного впливу на поширення хвороб, а також на високу ефективність фунгіциду Абакус, одержані дані дозволяють рекомендувати в сівозмінах розміщувати жито після квасолі та застосовувати пестицид як дієві елементи технології вирощування культури в місцевих грунтово-кліматичних умовах.

1. Абакус ${ }^{\circledR}$. Все працює на максимальний урожай. BASF. URL: https://www.agro.basf.ua.uk. (дата звернення: 10.10.2020).

2. Державний реєстр пестицидів і агрохімікатів, дозволених до використання в Україні за 2020 p. Міністерство захисту довкілля та природних ресурсів Украйни. URL: https://mepr.gov.ua/content/derzhavniy-reestr-pesticidiv-i-agrohimikativ-dozvolenih-do-vikoristannya-vukraini-dopovnennya-z-01012017-zgidno-vimog-postanovi-kabinetu-ministriv-ukraini-vid-21112007-1328.html. (дата звернення: 15.10.2020).

3. Державний реєстр сортів рослин, придатних для поширення в Україні на 2020 рік. Український інститут експертизи сортів рослин. URL: https://sops.gov.ua/reestr-sortiv-roslin. (дата звернення: 15.10.2020).

4. Інститут рослинництва ім. В.Я. Юр'єва Національної академії аграрних наук України. URL: http://www.yuriev.com.ua. (дата звернення: 17.09.2020).

5. Конончук О. Б., Давосир О. І. Продуктивність жита посівного (Secale cereale L.) за дії фунгіциду Абакус і різних попередників в умовах Тернопільської області. Perspectives of science and education: proceedings of the 12th International youth conference (New York, USA, September 27, 2019). New York, USA : SLOVOIWORD, 2019. P. 382-388.

6. Конончук О. Б. Навчальна практика з основ сільського господарства: навч. посіб. 3-е вид., виправ., допов. Тернопіль : ФОП Осадца Ю. В., 2020. 136 с.

7. Конончук О. Б. Практикум з основ сільського господарства : навч. посіб. 2-е вид., перероб. і доп. Тернопіль : Вектор, 2017. $148 \mathrm{c}$.

8. Косилович Г. О., Коханець О. М. Інтегрований захист рослин : навч. посіб. Львів : Львівський національний аграрний університет, 2010. 165 с.

9. Манько К., Музафаров Н. Вплив нетрадиційних попередників на сучасні сорти і гібриди жита озимого. Агроном. 2012. № 3. C. 86-91. URL: https://agronom.com.ua/vplyv-netradytsijnyhpoperednykiv-na/. (дата звернення: 12.09.2020).

ISSN 2078-2357. Наук. зап. Терноп. нац. пед. ун-ту. Сер. Біол., 2020, № 3-4 (80) 
10. Марков І. Л. Захищаємо озимі культури від хвороб. Агробізнес сьогодні. 2017. № 22. URL: http://agro-business.com.ua/agro/ahronomiia-sohodni/item/9394-zakhyshchaiemo-ozymi-kultury-vidkhvorob.html. (дата звернення: 14.09.2020).

11. Марков І. Л. Основні хвороби жита озимого та заходи щодо їх контролю. Агроном. 2016. № 4 (54). C. 68-72. URL: https://agronom.com.ua/ osnovni-hvoroby-zhyta-ozymogo-ta-zahody-shhodo-yihkontrolyu/. (дата звернення: 10.09.2020).

12. Наукові основи ведення зернового господарства / Сайко В. Ф. та ін. Київ : Урожай, 1994. 336 с.

13. Пересипкін В. Ф. Сільськогосподарська фітопатологія. Київ : Аграрна освіта, 2000. 416 с.

14. Реєстраційні випробування фунгіцидів у сільському господарстві / Ретьман С. В. та ін. Київ : Колобіг, 2013. 296 с.

15. Рослинництво. Технології вирощування сільськогосподарських культур / Лихочвор В. В. та ін.; за ред. Лихочвора В. В., Петриченка В.Ф. 3-є вид., виправ., допов. Львів : НВФ «Українські технології», 2010. 1088 с.

16. Рослинництво: підручник / Базалій В. В. та ін. Херсон : ОЛДИ-ПЛЮС, 2019. 520 с.

17. Сільськогосподарська фітопатологія: підручник / Марков І. Л. та ін.; за ред. І. Л. Маркова. Київ : Інтерсервіс, 2017. 574 c.

18. AgroScience. URL: http://agroscience.com.ua/plant. (Last accessed: 12.08.2020).

19. Food and Agriculture Organization of the United Nations. URL: http://www.fao.org/faostat/en/\#data/QC/ (Last accessed: 16.10.2020).

20. Growth stages of mono- and dicotyledonous plants: BBCH Monograph / Edited by Uwe Meier; Federal Biological Research Centre for Agriculture and Forestry. 2 Edition. Berlin; Boston: Blackwell Wissenschafts-Verlag, 2001. 158 p.

21. Flavonoids, anthocyanins, phenolamides, benzoxazinoids, lignans and alkylresorcinols in rye (Secale cereale) and some rye products / Pihlava Juha-Matti et all. Journal of Cereal Science. 2018. Vol. 79. P. 183-192. DOI: https://doi.org/10.1016/j.jcs.2017.09.009. (Last accessed: 12.09.2020).

22. Jouve N., McIntyre C. L., Gustafson J. P. Chromosome preparations from protoplasts: in situ hybridization banding pattern of a dispersed DNA sequence in rye (Secale cereale L.). Genome. 1991, Vol. 34(4). P. 524527. DOI: https://doi.org/10.1139/g91-080. (Last accessed: 10.08.2020).

\section{References}

1. Abacus $^{\circledR}$. Vse pracyuye na maksy`mal ny`j urozhaj. BASF. URL: https://www.agro.basf.ua.uk. [in Ukrainian]

2. Derzhavnyi reiestr pestytsydiv i ahrokhimikativ, dozvolenykh do vykorystannia v Ukraini za $2020 \mathrm{r}$. Ministerstvo zakhystu dovkillia ta pryrodnykh resursiv Ukrainy. URL: https://mepr.gov.ua/content/ derzhavniy-reestr-pesticidiv-i-agrohimikativ-dozvolenih-do-vikoristannya-v-ukraini-dopovnennya-z01012017-zgidno-vimog-postanovi-kabinetu-ministriv-ukraini-vid-21112007--1328.html. [in Ukrainian]

3. Derzhavnyi reiestr sortiv roslyn, prydatnykh dlia poshyrennia v Ukraini na 2020 rik. Ukrainskyi instytut ekspertyzy sortiv roslyn. URL: https://sops.gov.ua/reestr-sortiv-roslin. [in Ukrainian]

4. Instytut roslynnytstva im. V. Ya. Yurieva Natsionalnoi akademii ahrarnykh nauk Ukrainy. URL: http://www.yuriev.com.ua. [in Ukrainian]

5. Kononchuk O. B., Davosyr O. I. Produktyvnist zhyta posivnoho (Secale cereale L.) za dii funhitsydu Abakus i riznykh poperednykiv v umovakh Ternopilskoi oblasti. Perspectives of science and education: proceedings of the 12th International youth conference (New York, USA, September 27, 2019). New York, USA : SLOVOIWORD, 2019. P. 382-388. [in Ukrainian]

6. Kononchuk O. B. Navchalna praktyka z osnov silskoho hospodarstva: navch. posib. 3-e vyd., vyprav., dopov. Ternopil : FOP Osadtsa Yu. V., 2020. 136 s. [in Ukrainian]

7. Kononchuk O. B. Praktykum z osnov silskoho hospodarstva : navch. posib. 2-e vyd., pererob. i dop. Ternopil : Vektor, 2017. 148 s. [in Ukrainian]

8. Kosylovych H. O., Kokhanets O. M. Intehrovanyi zakhyst roslyn : navch. posib. Lviv : Lvivskyi natsionalnyi ahrarnyi universytet, 2010. 165 s. [in Ukrainian]

9. Manko K., Muzafarov N. Vplyv netradytsiinykh poperednykiv na suchasni sorty i hibrydy zhyta ozymoho. Ahronom. 2012. № 3. S. 86-91. URL: https://agronom.com.ua/vplyv-netradytsijnyh-poperednykiv-na/. [in Ukrainian]

10. Markov I. L. Zakhyshchaiemo ozymi kultury vid khvorob. Ahrobiznes sohodni. 2017. № 22. URL: http://agro-business.com.ua/agro/ahronomiia-sohodni/item/9394-zakhyshchaiemo-ozymi-kultury-vidkhvorob.html. [in Ukrainian] 
11. Markov I. L. Osnovni khvoroby zhyta ozymoho ta zakhody shchodo yikh kontroliu. Ahronom. 2016. № 4 (54). S. 68-72. URL: https://agronom.com.ua/ osnovni-hvoroby-zhyta-ozymogo-ta-zahody-shhodo-yihkontrolyu/. [in Ukrainian]

12. Naukovi osnovy vedennia zernovoho hospodarstva / Saiko V. F. ta in. Kyiv : Urozhai, 1994. 336 s. [in Ukrainian]

13. Peresypkin V. F. Silskohospodarska fitopatolohiia. Kyiv : Ahrarna osvita, 2000. 416 s. [in Ukrainian]

14. Reiestratsiini vyprobuvannia funhitsydiv u silskomu hospodarstvi / Retman S. V. ta in. Kyiv : Kolobih, 2013. 296 s. [in Ukrainian]

15. Roslynnytstvo. Tekhnolohii vyroshchuvannia silskohospodarskykh kultur / Lykhochvor V. V. ta in.; za red. Lykhochvora V. V., Petrychenka V. F. 3-ye vyd., vyprav., dopov. Lviv : NVF «Ukrainski tekhnolohii», 2010. 1088 s. [in Ukrainian]

16. Roslynnytstvo: pidruchnyk / Bazalii V. V. ta in. Kherson : OLDY-PLIUS, 2019. 520 s. [in Ukrainian]

17. Silskohospodarska fitopatolohiia: pidruchnyk / Markov I. L. ta in.; za red. I. L. Markova. Kyiv : Interservis, 2017. 574 s. [in Ukrainian]

18. AgroScience. URL: http://agroscience.com.ua/plant. (Last accessed: 12.08.2020).

19. Food and Agriculture Organization of the United Nations. URL: http://www.fao.org/faostat/en/\#data/QC/ (Last accessed: 16.10.2020).

20. Growth stages of mono- and dicotyledonous plants: BBCH Monograph / Edited by Uwe Meier; Federal Biological Research Centre for Agriculture and Forestry. 2 Edition. Berlin; Boston: Blackwell Wissenschafts-Verlag, 2001. 158 p.

21. Flavonoids, anthocyanins, phenolamides, benzoxazinoids, lignans and alkylresorcinols in rye (Secale cereale) and some rye products / Pihlava Juha-Matti et all. Journal of Cereal Science. 2018. Vol. 79. P. 183-192. DOI: https://doi.org/10.1016/j.jcs.2017.09.009. (Last accessed: 12.09.2020).

22. Jouve N., McIntyre C. L., Gustafson J. P. Chromosome preparations from protoplasts: in situ hybridization banding pattern of a dispersed DNA sequence in rye (Secale cereale L.). Genome. 1991, Vol. 34(4). P. 524-527. DOI: https://doi.org/10.1139/g91-080. (Last accessed: 10.08.2020).

O. B. Kononchuk, S. V. Pyda, A. I. Herts, N. V. Herts, O. B. Matsiuk, N. V. Moskalyuk Ternopil Volodymyr Hnatiuk National Pedagogical University, Ukraine

\section{THE INFLUENCE OF PREDECESSORS AND ABRACUS FUNGICIDES ON THE SPREAD OF} DISEASES AND PRODUCTIVITY OF RYE (SECALE CEREALE L.) IN TERNOPIL REGION

The article studies the value of beans and soybeans as precursors of winter sowing rye, and the effectiveness of the Abacus fungicide to reduce the spread of crop diseases in soil and climatic conditions of the Ternopil region.

The research proves that the pesticide reduces the spread of powdery mildew by 2.7 and $3.0 \%$, brown rust by 2.9 and $3.2 \%$, leaf septoria by 6.0 , and by $7.1 \%$ in the sowing of rye Kharkiv 98 . It shows high technical efficiency of application against the stated above diseases, in particular, 50.2 and $58.7 \%, 49.2$ and $46.9 \%, 69.5$ and $70.5 \%$ respectively.

The use of Abacus significantly increases the grain productivity of rye, which is sown after soybeans (by $2.06 \mathrm{t} / \mathrm{ha}$ ), compared to the predecessor of beans $(1.66 \mathrm{t} / \mathrm{ha})$. This increase in rye grain yield growth after the soybean precursor due to the fungicide is associated with a significant formation of plant density by $26.9 \%$, total by $36.1 \%$, and productive by $21.1 \%$, an increase in quantity (by $13.4 \%$ ) and the grains mass in the rye ears (by 19.1\%) and the higher increase in the biological yield of aboveground mass by $38.4 \%$ for the predecessor of soybeans, compared with the growth of these indicators by 2.8, 25.3, 18.6, 4.6, 9.5, 30.4\% accordingly, sowing rye after beans.

Despite the higher efficiency of the Abacus fungicide in sowing rye after soybean, for its productivity, a more important factor for crop formation was the predecessor, beans, which indicates a higher grain yield compared to the soybeans predecessor, as well as using the Abacus fungicide by $0.46 \mathrm{t} / \mathrm{ha}$, and also in the absence of chemical protection by $0.86 \mathrm{t} / \mathrm{ha}$.

Analysis of the elements of productivity showed that the higher value of beans as rye precursor, compared with soybeans, is realized, regardless of the use of pesticides, due to higher plant density by 41.6-74.8\%, total stem density by $21.7-32.2 \%$, and productive stems density by $17.5-20.0 \%$, as well as the increase of plant height by 3.1-8.8\%, which led to the increase in total biological yield by 38.2-46.6\% and its component, masses of straw, by 49.0-56.1\%. Measurement of rye ears length, 
counting the number of spikelets and grains in the inflorescences revealed a slight effect of predecessors on these indicators. Significant increase in vegetative mass of rye after the predecessor of beans and limited influence of both predecessors on the generative sphere of plants led to the decrease in grain yield in crops by 6.1-7.5\% compared to plants sown after soybeans, regardless of fungicide.

Given the higher value of beans compared to soybeans as precursors of rye in its productivity and lack of significant impact on spread of disease, as well as the high efficiency of the Abacus fungicide, it is recommended sewing rye after beans in crop rotation and use pesticides as a tool efficient in crop cultivation in local soil and climatic conditions.

Key words: rye, Secale cereale L., crop rotation, predecessor, bean, soybean, fungicide, Abacus, disease, productivity.

Надійшла 12.10.2020. 